\title{
Betawi Ethnic Family Communication Patterns in Building Awareness of the Importance of Higher Education for Daughters
}

\author{
Maulina Larasati Putri ${ }^{a, 1, *}$, Aminah Devina Fajri ${ }^{\mathrm{b}, 2}$, Ayu Priana ${ }^{\mathrm{c}, 3}$ \\ a,b,c,Universitas Negeri Jakarta \\ Email: ${ }^{1}$ maulinalarasati@unj.ac.id*; ${ }^{2}$ AminahDevinaFajri_1410618034@mhs.unj.ac.id; ${ }^{3}$ AyuPriana_1410618026@mhs.unj.ac.id \\ *corresponding author
}

Keywords:

Family Communication Patterns,

Higher Education, Ethnic Betawi

\begin{abstract}
Family is an essential aspect of human life and is also the first environment that will be an example for every individual, especially for a child. Family is the first place where children form their potential. The first education a child gets also comes from the family. Indonesia, which has various cultures, has differences in communication, especially communication within the family. In this study, the ethnicity we examined was the Betawi ethnicity, where previously, the Betawi people thought that education for daughters was not an obligation. Still, as the development of the cultural age also developed, we found many women from the Betawi ethnicity could teach higher education learners. The development of the cultural age is also influenced by the mindset instilled by the Betawi ethnic family through the instilled family communication pattern. In this study, researchers are interested in knowing how the communication patterns of Betawi ethnic families in building awareness of the importance of higher education for daughters. The method used in this research is a quantitative method by collecting data using a questionnaire which is distributed to 30 respondents. The respondents of this study were daughters from the Betawi ethnicity. This study indicates that the Betawi ethnic family tends to apply the balanced split pattern and the unbalanced split pattern. The flat split pattern prioritizes equality in roles and balanced tasks for each family member. Meanwhile, the unbalanced split pattern applies the opposite. This communication pattern is not balanced, and one of the dominant family members in the family.
\end{abstract}

Copyright $\odot 2021$ Channel Jurnal Komunikasi. All right reserved.

\section{INTRODUCTION}

Family is the essential aspect of human life and the immediate environment that each individual has, especially for a child. Every child gains experience, understanding, and knowledge as well as first-time interactions through the family. Through the family, children are guided to develop their potential and hone their creativity and learn social values well. Through family, children are well nurtured to face the future they will face.

In essence, the family is a place to form characteristics, patterns of thought and a place where humans socialize, especially with children. All these processes cannot be separated from the role and communication patterns of the family in it. Communication is an essential component in shaping children's characteristics and mindsets. That is because communication is a process that can always change ourselves and our social world (Malik, 2014).

A research about family communication patterns was conducted by Marfuah Sri Sanityastuti, Yani Tri Wijayanti and Alip Kunandar in 2015 with the title "Pola Komunikasi Keluarga dalam Membangun Akhlak Karimah". This research shows that individual communication is used on random things, while group communication is used in certain situations. Like when the family is spending time together for some activities, such as at dinner together or problems that need to be discussed in the family. In the end, the parents hope the children have good morals. However, as the immediate environment, the family has an essential task in forming a child's self, and the communication patterns that are applied in the family have a critical role (Wijayanti, 2015). 
According to Judy C. Pearson and Paul E. Nelson, communication has two general functions: (1) Communication exists for the survival of the individual, which includes physical safety and increasing personal awareness. (2) Communication exists for the community's survival and helps fix social relations and develop social conditions (Mulyana, 2003). In family communication, there are two functions, namely cultural functions, and social functions. In family communication, there are two functions, namely cultural functions, and social functions. The cultural function means that culture and communication have a reciprocal relationship, where culture enters and becomes part of communication. Meanwhile, the social function explains that communication is vital in shaping the self-concept and self-actualization, happiness, and avoiding tension and pressure (Rihi et al., 2018).

Communication between family members is essential in the family environment, especially communication between children and parents. Communication is a medium that connects harmony between family members. Family harmony and integrity can be formed if there is good quality communication in the family. In addition to maintaining harmony and family integrity, family communication also plays a significant role in children's education. The function of family communication is not very different from that of communication in general. There are two functions in family communication, namely: a social function and also a cultural function. The first is a social function. In Thecial function explains that communication is an essential component for establishing self-concept, self-actualization, obtaining happiness, and keeping away from pressure and tension. Second, there is a cultural function. Some sociologists have the view that there is a reciprocal relationship between communication as well as culture. Culture is a part of communication here and has a role in determining, developing, maintaining, and passing on culture (Hendri Gunawan, 2013).

In Indonesia, various kinds of tribes and ethnicities also have various kinds of beliefs and different cultures. Likewise, the way various tribes and ethnicities carry out family communication is undoubtedly different. Betawi ethnicity is one of the ethnic groups in Jakarta with various cultures, languages, and cultures. The diversity of colors in the Betawi ethnic culture brings various perceptions, interpretations, and knowledge of the Betawi ethnicity, both from the indigenous population, culture, or culture. Some believe that the Betawi people are of various kinds, in the sense that Betawi ethnicity comes from a mixture of blood from various ethnic groups and foreign nations (Purbasari, 2010).

Betawi ethnic groups, of course, have differences in family communication with other cultures. Especially in family communication about planting to children about an educational mindset. The Betawi people are famous for their vital religious education. However, in the past, the Betawi people thought that education for daughters was not an obligation, as evidenced by the term 3R for women, namely mattresses, wells, and kitchens. This term explains that daughters in the Betawi community are considered not to need higher education and only boys are led or considered capable of pursuing higher education.

Nevertheless, over time, culture has also developed along the lines of time. We find that many women from the Betawi ethnicity can pursue higher education. The women are also influenced by the mindset instilled by the Betawi ethnic family through the implanted family communication pattern. Education for daughters has now become one of the crucial things to do because, basically, smart women, thanks to higher education, will also significantly affect the quality of a family. According to a study entitled "Gender Equality and the Millennium Development Goals (2002)" from the World Bank, explaining the high number of illiteracy and low levels of education of a mother has a direct impact on the number of cases of malnutrition which is a result of low quality of care for babies and toddler (Z.A, 2018). Based on these facts, it cannot be denied that higher education for daughters is crucial, especially for the welfare and sustainability of building a family because women who will become mothers have a significant role. A smart mother will support the formation of a prosperous family and bright children too.

From the explanation above, the researcher wants to know how the communication patterns of the Betawi ethnic family in building awareness of the importance of higher education for daughters.

\section{LITERATURE REVIEW}

\section{A. Family Communication Patterns}

The family communication patterns hypothesis proposes that families act as a fundamental unit of socialization for children, wherein schemata for familial intuition are shaped and impact the preparation of messages (Hovick et al., 2019). The family environment is the first setting in which children learn behaviors and develop expectations for social life. Koerner \& Fitzpatrick explain that people create social patterns that set up their communication behavior in families. Two measurements contain family communication Pattern theory: conversation and congruity introduction. Discussion Introduction, already named concept-orientation, refers to the degree to which family members are free to communicate on various topics, even if they disagree (Curran \& Allen, 2017).

Communication patterns can be interpreted as a pattern of relationships between two or more people in sending and receiving messages in the right way so that the message can be understood (Pusungulaa et al., 2015). Family communication patterns describe a family's tendency to develop the most appropriate and appropriate way to communicate among family members (Wijayanti, 2015). Family communication patterns can be seen in how parents build communication with their 
children (Setyowati, 2005). Family communication patterns can also be interpreted as efforts made to create a family that understands and knows each other to create a harmonious atmosphere in the family (Rahmawati \& Gazali, 2018). In another sense, family communication patterns are defined as communication in a family where the source is from the child to their parent, or parents to their child who then has a particular pattern (Sari et al., 2010). From some of the above definitions, it can be concluded that the family communication pattern is a communication process that exists within the family, both from parent to child and child to parent, which can form a specific pattern.

According to De Vito (2001), there are several types of family communication patterns: The Equality Pattern, The Balanced Split Pattern, The Unbalanced Split Pattern, and the Monopoly Pattern. The first type of communication pattern, namely: (a) The Equality Pattern, explains that each family member has the same role or duty in expressing opinions, asking, or listening to something. Regarding the division of roles or duties in the family, it does not have to be the same, and fellow family members can change roles. Although the pattern of communication that is called balanced cannot consistently be implemented in practice and the division of roles does not have to be the same from time to time, this family communication pattern can be said to be balanced or equal. (b) The Balance Split Pattern is a family communication pattern that offers a balanced role or duty to each family member, but each family member still has a portion of their power. (c) The Unbalanced Split Pattern is an unbalanced family communication pattern in which a family member appears dominant over other family members. The superior person can control almost all decisions in the family. (d) The Monopoly Pattern is a family communication pattern that emphasizes one person's authority or power. Processes and ways of conveying messages tend to teach and proper orders or commands rather than communicating among family members. This person does not often ask other family members and has more rights to make a final decision in the family (Wardyaningrum, 2010).

\section{RESEARCH METHODS}

This research uses descriptive quantitative research methods. Quantitative studies are studies that explain studies hypotheses that may be proven following hypotheses predicted by researchers (Putri et al., 2020). Sugiyono (2014) says that the descriptive research method is defined as research aiming to describe and explain data by analyzing data that researchers have obtained to explain. The descriptive method also emphasizes the objective measurement aspects of a social phenomenon. The descriptive method aims to describe or paint systematically, factually, and accurately and facts, properties, and the relationship of the phenomena under study.

The population of this research is the Betawi ethnic family. This research uses the purposive sampling technique. According to Sugiono in Andriati (2015), purposive sampling is a technique of collecting samples through specific considerations. This study's sample consisted of 30 people who were daughters from Betawi families, both whose fathers and mothers came from the Betawi ethnicity or only the father or mother who came from the Betawi ethnicity, and we are currently studying in college.

The type of research method used for the data collection process of this research is the survey method. The instrument used in this research for data collection to obtain the results obtained is more systematic, complete, and easy to process by using a questionnaire or questionnaire. This study uses a closed questionnaire, a questionnaire that provides a written statement and several answer choices to answer one answer from several choices presented, and it is related to how they feel.

\section{RESULTS AND DISCUSSION}

Data collection has been carried out by researchers from several respondents who have carried out data collection respondents through distributed questionnaires. The data collection process was carried out in September 2020. All respondents are daughters from Betawi ethnic families who are currently pursuing higher education. Researchers want to see how their family's communication patterns in the awareness of higher education for girls. The following are answers from all respondents on each questionnaire statement that has been distributed.

Table 1. Each Family Member Has the Opportunity to Express Opinions

\begin{tabular}{|c|c|c|c|}
\hline Statement & Frequency & Percentage & Average \\
\hline 4 (SS) & 18 & $60 \%$ & \multirow{2}{*}{3,6} \\
\cline { 1 - 3 } $3(\mathrm{~S})$ & 12 & $40 \%$ & \\
\hline $2(\mathrm{TS})$ & 0 & $0 \%$ & \\
\hline 1 (STS) & 0 & $0 \%$ & \\
\hline Total & 30 & $100 \%$ & \\
\hline
\end{tabular}

From the table above, it can be seen that the mean value is 3.6, where the majority of respondents answered strongly agree (60\%) that each family member has the opportunity to express an opinion. 
Table 2. Opportunities to Talk About the Importance of Education

\begin{tabular}{|l|l|l|l|}
\hline Statement & Frequency & Percentage & Average \\
\hline $4(\mathrm{SS})$ & 18 & $60 \%$ & \\
\cline { 1 - 3 }$(\mathrm{S})$ & 12 & $40 \%$ & \multirow{3}{*}{3,6} \\
\cline { 1 - 3 }$(\mathrm{TS})$ & 0 & $0 \%$ & \\
\hline 1 (STS) & 0 & $0 \%$ & \\
\cline { 1 - 3 } Total & 30 & $100 \%$ & \\
\hline
\end{tabular}

From the table above, it can be seen that the mean value is 3.6 , where the majority of respondents answered strongly agree with the percentage $(60 \%)$, that every family member also has the opportunity to talk about the importance of education.

Table 3. Children Telling Problems on Campus to Parents

\begin{tabular}{|l|l|l|l|}
\hline Statement & Frequency & Percentage & Average \\
\hline $4(\mathrm{SS})$ & 10 & $33,5 \%$ & \\
\cline { 1 - 3 }$(\mathrm{S})$ & 15 & $50 \%$ & \multirow{2}{*}{2,83} \\
\cline { 1 - 3 }$(\mathrm{TS})$ & 5 & $16,7 \%$ & \\
\hline $1(\mathrm{STS})$ & 0 & $0 \%$ & \\
\cline { 1 - 3 } Total & 30 & $100 \%$ & \multirow{2}{*}{} \\
\hline
\end{tabular}

From the table above, it can be seen that the mean value is 2.83 , where the majority of respondents answered agree $(50 \%)$ that children can tell their parents about the problems they experience on campus.

Table 4. Feeling Comfortable in Telling Education Problems to the Father

\begin{tabular}{|l|l|l|l|}
\hline Statement & Frequency & Percentage & Average \\
\hline $4(\mathrm{SS})$ & 2 & $6,7 \%$ & \\
\cline { 1 - 3 }$(\mathrm{S})$ & 18 & $60 \%$ & \multirow{2}{*}{2,6} \\
\cline { 1 - 3 }$(\mathrm{TS})$ & 8 & $26,6 \%$ & \\
\hline $1(\mathrm{STS})$ & 2 & $6,7 \%$ & \\
\hline Total & 30 & $100 \%$ & \\
\hline
\end{tabular}

From the table above, it can be seen that the mean value is 2.6 , where the majority of respondents answered agree $(60 \%)$ that they feel comfortable when telling their father about education problems.

Table 5. Feeling Comfortable in Sharing Education Problems with the Mother

\begin{tabular}{|l|l|l|l|}
\hline Statement & Frequency & Percentage & Average \\
\hline $4(\mathrm{SS})$ & 17 & $56,7 \%$ & \\
\cline { 1 - 3 }$(\mathrm{S})$ & 11 & $36,7 \%$ & \multirow{3}{*}{3,5} \\
\cline { 1 - 3 }$(\mathrm{TS})$ & 2 & $6,7 \%$ & \\
\hline 1 (STS) & 0 & $0 \%$ & \\
\hline Total & 30 & $100 \%$ & \\
\cline { 1 - 3 }
\end{tabular}

From the table above, the mean value of the above statement is 3.5 , with the majority of respondents strongly agree with a percentage of $56.7 \%$ that they have a sense of comfort when telling their mother about educational problems.

Table 6. Children Only Tell Problems on Campus When Parents Ask Them

\begin{tabular}{|l|l|l|l|}
\hline Statement & Frequency & Percentage & Average \\
\hline $4(\mathrm{SS})$ & 4 & $13,3 \%$ & \\
\cline { 1 - 3 } $3(\mathrm{~S})$ & 18 & $60 \%$ & \multirow{2}{*}{2,86} \\
\hline $2(\mathrm{TS})$ & 8 & $26,7 \%$ & \\
\hline 1 (STS) & 3.53 .40 & $0 \%$ & \\
\hline Total & 30 & $100 \%$ & \\
\hline
\end{tabular}

From the table above, it can be seen that the mean value is 2.86 where the majority of respondents answered agree $(60 \%)$ that they only talked about problems on campus when parents asked first. 
Table 7. Children Listen to Parents When Parents Give Advice

\begin{tabular}{|l|l|l|l|}
\hline Statement & Frequency & Percentage & Average \\
\hline $4(\mathrm{SS})$ & 14 & $46,7 \%$ & \\
\cline { 1 - 3 }$(\mathrm{S})$ & 16 & $53,3 \%$ & \multirow{3}{*}{3,46} \\
\cline { 1 - 3 }$(\mathrm{TS})$ & 0 & $0 \%$ & \\
\hline 1 (STS) & 0 & $0 \%$ & \\
\cline { 1 - 3 } Total & 30 & $100 \%$ & \\
\hline
\end{tabular}

From the table above, the mean value is 3.46 where most respondents answered agree $(53.3 \%)$ that they listen to their parents when their parents give advice.

Table 8. Father Always Gives Advice When Children Have Problems on Campus

\begin{tabular}{|l|l|l|l|}
\hline Statement & Frequency & Percentage & Average \\
\hline $4(\mathrm{SS})$ & 5 & $16,7 \%$ & \\
\cline { 1 - 3 }$(\mathrm{S})$ & 18 & $60 \% \%$ & \multirow{2}{*}{2,93} \\
\hline $2(\mathrm{TS})$ & 7 & $23,3 \%$ & \\
\hline $1(\mathrm{STS})$ & 0 & $0 \%$ & \\
\hline Total & 30 & $100 \%$ & \\
\hline
\end{tabular}

From the table above, it can be seen that the mean value is proved to be 2.93 , which the majority of respondents agreed $(60 \%)$ that the father always gives advice when the child has problems on campus.

Table 9. Mothers Always Give Advice When Children Have Problems on Campus

\begin{tabular}{|l|l|l|l|}
\hline Statement & Frequency & Percentage & Average \\
\hline $4(\mathrm{SS})$ & 17 & $56,7 \%$ & \\
\cline { 1 - 3 }$(\mathrm{S})$ & 12 & $40 \%$ & \multirow{3}{*}{3,53} \\
\cline { 1 - 3 }$(\mathrm{TS})$ & 1 & $3,3 \%$ & \\
\hline $1(\mathrm{STS})$ & 0 & $0 \%$ & \\
\hline Total & 30 & $100 \%$ & \\
\cline { 1 - 3 } & &
\end{tabular}

From the table above, it can be seen that the mean value of this statement is 3.53, where the majority of respondents answered strongly agree $(56.7 \%)$ that mothers always provide advice when children have problems on campus.

Table 10. Children Ask Father for Input Regarding Education

\begin{tabular}{|l|l|l|l|}
\hline Statement & Frequency & Percentage & Average \\
\hline $4(\mathrm{SS})$ & 6 & $20 \%$ & \\
\cline { 1 - 3 }$(\mathrm{S})$ & 15 & $50 \%$ & \multirow{2}{*}{2,83} \\
\hline $2(\mathrm{TS})$ & 8 & $26,7 \%$ & \\
\hline $1(\mathrm{STS})$ & 0 & $0 \%$ & \\
\hline Total & 30 & $100 \%$ & \\
\hline
\end{tabular}

From the table above, it can be seen that the mean value of this statement is 2.83 , of which the majority of respondents agreed (50\%) that they asked their father for input regarding education.

Table 11. Children Asking Mother for Input Regarding Education

\begin{tabular}{|l|l|l|l|}
\hline Statement & Frequency & Percentage & Average \\
\hline $4(\mathrm{SS})$ & 14 & $46,7 \%$ & \\
\cline { 1 - 3 }$(\mathrm{S})$ & 14 & $46,7 \%$ & \multirow{3}{*}{3,4} \\
\hline $2(\mathrm{TS})$ & 2 & $6,7 \%$ & \\
\hline 1 (STS) & 0 & $0 \%$ & \\
\cline { 1 - 3 } Total & 30 & $100 \%$ & \\
\hline
\end{tabular}

From the table above, it can be seen that the mean value is 3.4, which the majority of respondents answered agree $(46.7 \%)$ that they asked for input from mothers regarding education. 
Table 12. Each Family Member Can Change Roles To Remind One Another of the Importance of Education for Daughter

\begin{tabular}{|l|l|l|l|}
\hline Statement & Frequency & Percentage & Average \\
\hline $4(\mathrm{SS})$ & 12 & $40 \%$ & \\
\cline { 1 - 3 }$(\mathrm{S})$ & 17 & $56,7 \%$ & \multirow{3}{*}{3,36} \\
\hline $2(\mathrm{TS})$ & 1 & $3,3 \%$ & \\
\hline $1(\mathrm{STS})$ & 0 & $0 \%$ & \\
\hline Total & 30 & $100 \%$ & \\
\hline
\end{tabular}

From the table above, it is known that the mean value is 3.36, with the majority of respondents answering firmly $(56.7 \%)$ that each family member can change roles to remind each other of the importance of education for daughters.

Table 13. Each Family Member Reminds Each Other of the Importance of Education for Daughter

\begin{tabular}{|l|l|l|l|}
\hline Statement & Frequency & Percentage & Average \\
\hline $4(\mathrm{SS})$ & 14 & $46,7 \%$ & \\
\cline { 1 - 3 }$(\mathrm{S})$ & 15 & $50 \%$ & \multirow{3}{*}{3,43} \\
\hline $2(\mathrm{TS})$ & 1 & $3,3 \%$ & \\
\hline $1(\mathrm{STS})$ & 0 & $0 \%$ & \\
\hline Total & 30 & $100 \%$ & \\
\hline
\end{tabular}

From the table above, it can be seen that the mean value is 3.43 , with the majority of respondents agreeing $(50 \%)$ that each family member reminds each other of the importance of education for daughters.

Table 14. Family members have a balanced role and duty in raising awareness of the importance of higher education for daughters.

\begin{tabular}{|l|l|l|l|}
\hline Statement & Frequency & Percentage & Average \\
\hline $4(\mathrm{SS})$ & 11 & $36,7 \%$ & \\
\cline { 1 - 3 }$(\mathrm{S})$ & 19 & $63,3 \%$ & \multirow{3}{*}{3,36} \\
\cline { 1 - 3 }$(\mathrm{TS})$ & 0 & $0 \%$ & \\
\hline $1(\mathrm{STS})$ & 0 & $0 \%$ & \\
\hline Total & 30 & $100 \%$ & \\
\cline { 1 - 3 } & &
\end{tabular}

From the table above, it can be seen that the mean value is 3.36, and the majority of respondents agreed (63.3\%) that their family members have a balanced role and duty in increasing awareness of the importance of higher education for daughters.

Table 15. Family members have their respective duties and roles in increasing awareness of the importance of higher education for daughters.

\begin{tabular}{|l|l|l|l|}
\hline Statement & Frequency & Percentage & Average \\
\hline $4(\mathrm{SS})$ & 10 & $33,3 \%$ & \\
\cline { 1 - 3 }$(\mathrm{S})$ & 20 & $66,7 \%$ & \multirow{3}{*}{3,33} \\
\hline $2(\mathrm{TS})$ & 0 & $0 \%$ & \\
\hline $1(\mathrm{STS})$ & 0 & $0 \%$ & \\
\cline { 1 - 3 } Total & 30 & $100 \%$ & \\
\hline
\end{tabular}

From the table above, it can be seen that the mean value is 3.33 and the majority of respondents agree $(66.7 \%)$ that their family members have their respective portions and duties, and roles in increasing awareness of the importance of higher education for daughters.

Table 16. Family members have their respective powers in raising awareness of the importance of higher education for daughter

\begin{tabular}{|l|l|l|l|}
\hline Statement & Frequency & Percentage & Average \\
\hline $4(\mathrm{SS})$ & 7 & $23,3 \%$ & \\
\cline { 1 - 3 }$(\mathrm{S})$ & 22 & $73,3 \%$ & \multirow{3}{*}{3,2} \\
\cline { 1 - 3 }$(\mathrm{TS})$ & 1 & $3,3 \%$ & \\
\hline 1 (STS) & 0 & $0 \%$ & \\
\cline { 1 - 3 } Total & 30 & $100 \%$ & \\
\hline
\end{tabular}


From the table above, it can be seen that the mean value is 3.2, with the majority of respondents agreeing $(73.3 \%)$ that their family members have respective power in increasing awareness of the importance of higher education for daughters.

Table 17. There are family members who are dominant in raising awareness of the importance of higher education for the daughter

\begin{tabular}{|l|l|l|l|}
\hline Statement & Frequency & Percentage & Average \\
\hline $4(\mathrm{SS})$ & 14 & $46,7 \%$ & \\
\cline { 1 - 3 }$(\mathrm{S})$ & 13 & $43,3 \%$ & \multirow{3}{*}{3,36} \\
\hline $2(\mathrm{TS})$ & 3 & $10 \%$ & \\
\hline $1(\mathrm{STS})$ & 0 & $0 \%$ & \\
\hline Total & 30 & $100 \%$ & \\
\hline
\end{tabular}

From the table above, it can be seen that the mean value is 3.36 , with the majority of respondents strongly agree $(46.7 \%)$ that there are family members who are dominant in increasing awareness of the importance of higher education for daughters.

Table 18. These more dominant family members control almost all family decisions, including raising awareness of the importance of higher education for daughters.

\begin{tabular}{|l|l|l|l|}
\hline Statement & Frequency & Percentage & Average \\
\hline $4(\mathrm{SS})$ & 12 & $40 \%$ & \\
\cline { 1 - 3 }$(\mathrm{S})$ & 13 & $43,3 \%$ & \multirow{3}{*}{3,23} \\
\cline { 1 - 3 }$(\mathrm{TS})$ & 5 & $16,7 \%$ & \\
\hline $1(\mathrm{STS})$ & 0 & $0 \%$ & \\
\cline { 1 - 3 } Total & 30 & $100 \%$ & \\
\hline
\end{tabular}

From the table above, it can be seen that the mean value is 3.23 , with the majority of respondents agreeing $(43.3 \%)$ that their more dominant family member controls almost all family decisions, including regarding raising awareness of the importance of higher education for children and daughters.

Table 19. In the family, fathers have the authority or power to increase awareness of the importance of higher education for daughters.

\begin{tabular}{|l|l|l|l|}
\hline Statement & Frequency & Percentage & Average \\
\hline $4(\mathrm{SS})$ & 6 & $6 \%$ & \\
\cline { 1 - 3 }$(\mathrm{S})$ & 20 & $66,7 \%$ & \multirow{3}{*}{3,06} \\
\hline $2(\mathrm{TS})$ & 4 & $13,3 \%$ & \\
\hline $1(\mathrm{STS})$ & 0 & $0 \%$ & \\
\cline { 1 - 3 } Total & 30 & $100 \%$ & \\
\hline
\end{tabular}

From the table above, it can be seen that the mean value is 3.06, with the majority of respondents agreeing $(66.7 \%)$ that in their families, fathers have the authority or power in increasing awareness of the importance of higher education for daughters.

Table 20. In the family, mothers have the authority or power to raise awareness of the importance of higher education for daughters.

\begin{tabular}{|l|l|l|l|}
\hline Statement & Frequency & Percentage & Average \\
\hline $4(\mathrm{SS})$ & 11 & $36,7 \%$ & \\
\cline { 1 - 3 }$(\mathrm{S})$ & 16 & $53,3 \%$ & \multirow{3}{*}{3,26} \\
\hline $2(\mathrm{TS})$ & 3 & $10 \%$ & \\
\hline 1 (STS) & 0 & $0 \%$ & \\
\cline { 1 - 3 } Total & 30 & $100 \%$ & \\
\hline
\end{tabular}

From the table above, it can be seen that the mean value is 3.26, with the majority of respondents agreeing (53.3\%) that in their families, mothers have the authority or power in increasing awareness of the importance of higher education for daughters. 
Table 21. In conveying messages, family members tend to teach about increasing awareness of the importance of higher education for daughters.

\begin{tabular}{|l|l|l|l|}
\hline Statement & Frequency & Percentage & Average \\
\hline $4(\mathrm{SS})$ & 6 & $20 \%$ & \\
\cline { 1 - 3 }$(\mathrm{S})$ & 21 & $70 \%$ & \multirow{3}{*}{3,07} \\
\hline $2(\mathrm{TS})$ & 2 & $6,7 \%$ & \\
\hline $1(\mathrm{STS})$ & 1 & $3,3 \%$ & \\
\hline Total & 30 & $100 \%$ & \\
\hline
\end{tabular}

From the table above, it can be seen that the mean value is 3.07 , with the majority of respondents agreeing $(70 \%)$ that in conveying messages, family members tend to seem to teach about increasing awareness of the importance of higher education for daughters.

Table 22. In conveying messages regarding awareness of the importance of higher education, family members tend to convey in a tone of command.

\begin{tabular}{|l|l|l|l|}
\hline Statement & Frequency & Percentage & Average \\
\hline $4(\mathrm{SS})$ & 0 & $0 \%$ & \multirow{2}{*}{2,4} \\
\hline $3(\mathrm{~S})$ & 13 & $43,3 \%$ & \\
\hline $2(\mathrm{TS})$ & 16 & $53,3 \%$ & \\
\hline $1(\mathrm{STS})$ & 1 & $3,3 \%$ & \\
\hline Total & 30 & $100 \%$ & \\
\hline
\end{tabular}

From the table above, it can be seen that the mean value is 2.4 , with the majority of respondents answering disagree $(53.3 \%)$ that in conveying messages about awareness of the importance of higher education, their family members tend to convey in a tone of command.

Table 23. Fathers rarely ask other family members about the importance of higher education for their daughters.

\begin{tabular}{|l|l|l|l|}
\hline Statement & Frequency & Percentage & Average \\
\hline $4(\mathrm{SS})$ & 2 & $6,7 \%$ & \\
\cline { 1 - 3 }$(\mathrm{S})$ & 11 & $36,7 \%$ & \multirow{2}{*}{2,4} \\
\cline { 1 - 3 }$(\mathrm{TS})$ & 14 & $46,7 \%$ & \\
\hline 1 (STS) & 3 & $10 \%$ & \\
\hline Total & 30 & $100 \%$ & \\
\hline
\end{tabular}

From the table above, it can be seen that the mean value is 2.4 , with the majority of respondents answering disagree $(46.7 \%)$ that their fathers rarely ask other family members about the importance of higher education for daughters.

Table 24. Mothers rarely ask other family members about the importance of higher education for their daughters.

\begin{tabular}{|l|l|l|l|}
\hline Statement & Frequency & Percentage & Average \\
\hline $4(\mathrm{SS})$ & 1 & $3,3 \%$ & \\
\cline { 1 - 3 }$(\mathrm{S})$ & 6 & $20 \%$ & \multirow{2}{*}{1,43} \\
\hline $2(\mathrm{TS})$ & 15 & $50 \%$ & \\
\hline $1(\mathrm{STS})$ & 8 & $26,7 \%$ & \\
\hline Total & 30 & $100 \%$ & \\
\hline
\end{tabular}

From the table above, it can be seen that the mean value is 1.43 , which means that more respondents disagree $(50 \%)$ that their mothers rarely ask other family members about the importance of higher education for daughters.

Table 25. Fathers have more rights in determining higher education decisions.

\begin{tabular}{|l|l|l|l|}
\hline Statement & Frequency & Percentage & Average \\
\hline $4(\mathrm{SS})$ & 3 & $10 \%$ & \\
\cline { 1 - 3 }$(\mathrm{S})$ & 17 & $56,7 \%$ & \multirow{2}{*}{2,73} \\
\cline { 1 - 3 }$(\mathrm{TS})$ & 9 & $30 \%$ & \\
\hline 1 (STS) & 1 & $3,3 \%$ & \\
\hline Total & 30 & $100 \%$ & \\
\hline
\end{tabular}

From the table above, it can be seen that the mean value is 2.73 , with the majority of respondents agreeing $(56.7 \%)$ that their fathers have more rights in determining higher education decisions for daughters.

Table 26. Mothers have more rights in determining higher education decisions. 


\begin{tabular}{|l|l|l|l|}
\hline Statement & Frequency & Percentage & Average \\
\hline $4(\mathrm{SS})$ & 2 & $6,7 \%$ & \\
\cline { 1 - 3 }$(\mathrm{S})$ & 17 & $56,7 \%$ & \multirow{2}{*}{2,6} \\
\cline { 1 - 3 }$(\mathrm{TS})$ & 10 & $33,3 \%$ & \\
\cline { 1 - 3 }$(\mathrm{STS})$ & 1 & $3,3 \%$ & \\
\hline Total & 30 & $100 \%$ & \\
\hline
\end{tabular}

From the table above, it can be seen that the mean value is 2.6 , with the majority of respondents agreeing $(56.7 \%)$ that their mothers have more rights in determining higher education decisions for daughters.

From the tables above, it can be seen that between fathers and mothers, mothers tend to ask other family members more often about the importance of higher education for daughters. The data can be seen from tables 23 and 24. Meanwhile, the father figure is more dominant in determining and deciding about higher education for daughters. This data can be seen in tables 25 and 26.

After knowing the average value per questionnaire statement, such as the tables above, it can be obtained the mean or average value of each dimension. The following are the mean values per dimension.

Table 27. Means Per Dimension

\begin{tabular}{lc}
\hline Dimension & Mean \\
\hline The Equality Pattern & 3,22 \\
\hline The Balanced Split Pattern & 3,29 \\
\hline The Unbalanced Split Pattern & 3,29 \\
\hline Monopoly Pattern & 2,61 \\
\hline
\end{tabular}

From the table above, it can be seen that there are two dimensions that have the highest value, namely the dimensions of the balanced split pattern and the unbalanced split pattern with a mean value of 3.29. The third highest dimension is the equality pattern with a mean value of 3,22 . While the dimension with the lowest mean value is the monopoly pattern with a mean value of 2,61 .

From these data, it can be seen that the average Betawi ethnic family who became the respondents of this study applied the most commonly the balanced split pattern and the unbalanced split pattern in building awareness of the importance of higher education for daughters in their families. The data shows that with the balance split pattern family communication, the Betawi ethnic family tends to offer a balanced role or task to each family member in building awareness of the importance of higher education for daughters. However, in this family communication pattern, each family member still has a position in their respective power. So, it can be said that every time they are aware of the importance of higher education for girls, families with a balanced communication pattern and each family member still has the same position in the family.

Meanwhile, with the unbalanced split pattern, communication patterns tend to be unbalanced. One family member appears dominant compared to other families. In this case, it is usually the father or mother. Due to parents' dominance, they can also control almost all decisions in the family, including building awareness of the importance of higher education for daughters. So, families with this communication pattern tend to be controlled by someone dominant to increase awareness about the importance of higher education for daughters.

The lowest dimension mean value falls to the monopoly pattern communication pattern, which shows that Betawi ethnic families tend not to apply this communication pattern in building awareness of the importance of higher education for daughters.

From this, it can also be concluded that in each Betawi Ethical family, applying different communication patterns in building awareness of the importance of higher education for daughters. However, the majority use the balanced split pattern and the unbalanced split pattern. The communication patterns used also vary because they are following the circumstances of each family.

\section{CONCLUSION}

Family is the most crucial aspect in every relationship, including family relationships. Through communication, all family members interact with each other, including instilling values or understanding, especially from parents to their children. The pattern of communication applied to each family also affects how the values or understanding are applied in the family. Regarding higher education, especially for daughters, it is often considered not very important by some people. Whereas in fact, women have an essential role in every family, because later they are the ones who will educate and raise their children. Therefore, researchers are interested in knowing what communication patterns are applied in each family, 
especially the Betawi ethnic family, to build awareness of the importance of higher education for daughters.

This study indicates that the Betawi ethnic family tends to apply the balanced split pattern and the unbalanced split pattern, in which the balanced split pattern prioritizes equality in the roles and tasks that are balanced for each family member. Meanwhile, the unbalanced split pattern applies the opposite. This communication pattern is not balanced, and one of the dominant family members in the family.

Researchers hope that the results of this research can be used for other purposes, either for similar research or used for practice in daily activities.

\section{REFERENCES}

[1] [1] Andriati, N. (2015). Pengembangan Model Bimbingan Klasikal Dengan Teknik Role Playing Untuk Meningkatkan Kepercayaan Diri. Jurnal Bimbingan Konseling, 4(1), 36-42.

[2] [2] Curran, T., \& Allen, J. (2017). Family Communication Patterns, Self-Esteem, and Depressive Symptoms: The Mediating Role of Direct Personalization of Conflict. Communication Reports, 30(2), 80-90. https://doi.org/http:// dx.doi.org/10.1080/08934215.2016.1225224

[3] [3] Hendri Gunawan. (2013). Jenis Pola Komunikasi Orang Tua Dengan Anak Perokok Aktif Di Desa Jembayan Kecamatan Loa Kulu Kabupaten Kutai Kartanegara. Ilmu Komunikasi, 1(3), 218-233.

[4] [4] Hovick, S. R., Thomas, S. N., Watts, J., \& Tan, N. Q. P. (2019). The Influence of Family Communication Patterns on the Processing of Messages to Increase Family Health History Seeking Intentions. Health Communication, 1-9. https://doi.org/https://doi.org/10.1080/10410236.2019.1693129

[5] [5] Mulyana, D. (2003). Ilmu Komunikasi: Suatu Pengantar. Remaja Rosda Karya.

[6] [6] Malik, A. (2014). Fungsi Komunikasi Antara Guru dan Siswa dalam Meningkatkan Kualitas Pendidikan (Studi Kasus Proses Belajar Mengajar pada SMP Negeri 3 Sindue). Interaksi: Jurnal Ilmu Komunikasi, 3(2), $168-173$. https://doi.org/https://doi.org/10.14710/interaksi.3.2.168-173

[7] [7] Purbasari, M. (2010). Indahnya Betawi. Humaniora, 1(1), 1. https://doi.org/10.21512/humaniora.v1i1.2142

[8] [8] Pusungulaa, A., Pantow, J., \& Boham, A. (2015). Pola Komunikasi Keluarga dalam Membentuk Karakter Anak di Kelurahan Beo Talaud. E-Journal “Acta Diurna,” 4(1), 1-10.

[9] [9] Putri, K. Y. S., Abdullah, Z. Bin, Safitri, D., Sugiyatna, L., \& Ramdan, A. K. (2020). Framing of Health Communication on Content Islamic Religious Education in New Media. Hayula Indonesian Journal of Multidis Ciplinary Islamic Studies, 4(2), 189-202. https://doi.org/https://doi.org/10.21009/hayula.004.02.03

[10] [10] Rahmawati, \& Gazali, M. (2018). Pola Komunikasi dalam Keluarga. Al-Munzir: Jurnal Kajian Ilmu-Ilmu Komunikasi Dan Bimbingan Islam, 11(2), 327-245. https://doi.org/http://dx.doi.org/10.31332/am.v11i2.1125

[11] [11] Rihi, L. N. K., Manafe, Y. D., \& Hana, F. T. (2018). Fungsi Komunikasi Keluarga dalam Pembentukan Kepribadian Remaja di Kelurahan Sikumana Kecamatan Maulafa Kota Kupang. Jurnal Communio: Jurnal Jurusan Ilmu Komunikasi, 7(2), 1202-1224. https://doi.org/DOI: https://doi.org/10.35508/jikom.v7i2.2039

[12] [12] Sari, A., Hubeis, A. V. S., Mangkuprawira, S., \& Saleh, A. (2010). Pengaruh Pola Komunikasi Keluarga dalam Fungsi Sosialisasi Keluarga terhadap Perkembangan Anak. Jurnal Komunikasi Pembangunan, 8(2), 36-45. https:// doi.org/https://doi.org/10.46937/820105701

[13] [13] Setyowati, Y. (2005). Pola Komunikasi Keluarga dan Perkembangan Emosi Anak (Studi Kasus Penerapan Pola Komunikasi Keluarga dan Pengaruhnya Terhadap Perkembangan Emosi Anak pada Keluarga Jawa). Jurnal Ilmu Komunikasi, 2(1), 67-78. https://doi.org/https://doi.org/10/24002/jik.v2i1.253

[14] [14] Sugiyono. (2014). Metode Penelitian Pendidikan Pendekatan Kuantitatif, Kualitatif Dan R\&D. Alfabeta.

[15] [15] Wardyaningrum, D. (2010). Pola Komunikasi Keluarga dalam Menentukan Konsumsi Nutrisi bagi Anggota Keluarga. Jurnal Ilmu Komunikasi, 8(3), 289-298.

[16] [16] Wijayanti, Y. T. (2015). Pola Komunikasi Keluarga dalam Membangun Akhlakul Karimah. CHANNEL Jurnal Komunikasi, 3(2), 113-122. https://doi.org/10.12928/channel.v3i2.3278

[17] [17] Z.A, M. F. (2018). Konsep Pendidikan Anak Perempuan Pada Masyarakat Betawi. Jurnal Harkat: Media Komunikasi Gender, 14(1), 59-74. https://doi.org/10.15408/harkat.v14i1.10401 